hjelp for nødstilte (4). Flere helseforetak ønsker å legge til rette for at leger engasjerer seg $(5,6)$. Foretakene har samtidig ansvar for å sikre nok personell til forsvarlig drift.

Legen som arbeidstaker i lavinntektsland har hatt varierende sikring knyttet til pensjon, sykdom og eventuell arbeidsuførhet. Helseforetak som har personellutvekslingsprogrammer sikrer slike retter ved at legen er ansatt i foretaket også under oppholdet ute. Dersom man oppholder seg mer enn 12 måneder i utlandet, er det viktig å sikre medlemskap i folketrygden. Dekning av eventuell langvarig arbeidsuførhet etter oppholdet vil være avhengig av avtale med arbeidsgiver. Det er også viktig at legen sikres mot personlig ansvar ved søksmål fra pasient og pårørende. Slike avtaler kan være krevende å inngå for den enkelte lege, og Legeforeningen har nå sørget for at slik dekning for verdens 20 fattigste land er inkludert $\mathrm{i}$ ansvarsforsikringen.

Legeforeningen ønsker å være med på å legge til rette for at norske leger kan arbeide i lavinntekts- og mellominntektsland (3). Det er derfor viktig at temaer som de Kristiansen og Flaatten tar opp, formidles til foreningen. Slik informasjon kan bidra til foreningens politiske strategi, arbeidet med avtaler, videre- og etterutdanning samt vår aktivitet i Norsk helsenettverk for utvikling og andre norske fora. Leger som har erfaring fra eller har pågående engasjement $i$ lavinntekts- og mellominntektsland, oppfordres til å skrive en kort orientering og sende dette til utvalg for internasjonal helse ved leder Hilde Engjom eller sekretær Bjørn Oscar Hoftvedt i Legeforeningen.

\section{Hilde Engjom}

Bergen

Hilde Engjom (f. 1974) er lege i spesialisering ved Kvinneklinikken i Helse-Bergen. Hun har ledet Legeforeningens utvalg for internasjonal helse siden 2007 og har vært sentralstyremedlem i foreningen og leder av Yngre legers forening.

\section{Litteratur}

1. Flaatten K. Humanitært arbeid må telle. Tidsskr Nor Legeforen 2011; 131: 337

2. Kristiansen TH. Omkostninger ved humanitært arbeid. Tidsskr Nor Legeforen 2011; 131: 801-2.

3. Styrket samarbeid om utdanning av leger i lav- og mellominntektsland. Policydokument nr. 1/2010. Oslo: Den norske legeforening, 2010.

4. A2-avtalen. www.legeforeningen.no/asset/49223/ 1/49223 1.pdf (30.8.2011).

5. Bergen og Ullevål. http://innsiden.helse-bergen.no/ SiteDirectory /eis/Nyheter/Sider/ InternasjonaltsamarbeidmellomHaukelandog Ullevaal.aspx5 (30.8.2011).

6. Universitetet i Troms $\varnothing$ og Universitetssykehuset Nord-Norge. www2.uit.no/ikbViewer/page/ ansatte/organisasjon/internasjonalisering? p dimension id $=88127 \& p$ menu $=65794 \& p$ lang $=2$ (30.8.2011).

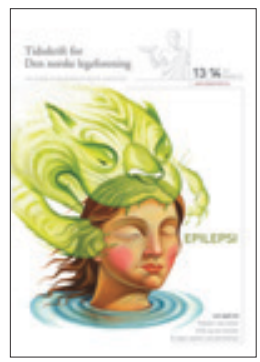

\section{Slaginsidens og motsetninger}

Wyller \& Fure kommenterer i Tidsskriftet nr. 13-14/2011 (1) våre artikler om hjerneslag i Bergen $(2,3)$. Forfatterne er overrasket over den lave årsinsidensen på 105 per 100000 og antyder seleksjonsmekanismer som årsak til dette. Nevrologisk avdeling ved Haukeland universitetssykehus har en åpen innleggelsespolitikk. Alle pasienter med mistenkt hjerneslag innlegges som øyeblikkelig hjelp. Hos $50 \%$ av de innlagte viser det seg at det ikke er nevrovaskulær sykdom. Dette indikerer at det ikke foretas seleksjon ved innleggelse. Befolkningsgrunnlaget er representativt og inkluderer alle aldersgrupper. Nevrologisk avdeling har i mange år hatt NORSTROKE forskningsregister, hvor alle data kvalitetssikres før registrering. Våre insidenstall er derfor valide.

Wyller \& Fure refererer til tall fra Haraldsplass Diakonale sykehus i Bergen, som gir en årsinsidens på «minst 183». Sykehuset har ikke noe slagregister, tallene er basert på utskrivningsdiagnoser og er ikke kvalitetssikret. I 2010 ble sykehusavdelinger der man behandler akutt hjerneslag bedt om å angi antall slagpasienter innlagt per år og befolkningens størrelse. Beregnede insidenstall ble lagt frem ved den 14 . Bergens-konferansen om nevrovaskulære sykdommer høsten 2010. Insidensen av hjerneslag var ved Akershus universitetssykehus 169, ved Oslo universitetssykehus, Ullevål, 260 og ved Lillehammer sykehus 471. I Helse Midt-Norge var insidensen i Namsos 203, i Ålesund 325, ved St. Olavs hospital 329 og i Orkanger 403. I Helse Nord varierte insidensen fra 364 (Hammerfest) til 792 (Harstad). Egenrapporterte insidenstall uten kvalitetssikring er usikre, og variasjonene er neppe reelle. At våre insidenstall er lavere «enn hva som er funnet ellers i Norge» er riktig, men vitenskapelig baserte insidenstall er 16-17 år gamle og ikke nødvendigvis representative i dag.

Wyller \& Fure understreker at «usynlige») utfall kan gi store problemer for pasient og pårørende hvis de ikke blir diagnostisert og behandlet. Dette er korrekt. Nettopp derfor anbefaler vi en åpen innleggelsespolitikk også for pasienter med lette eller subtile akuttnevrologiske symptomer. Slike symptomer kan fort oppfattes som transitoriske eller ikke-nevrologiske, og pasientene risikerer enten ingen nevrologisk utredning eller en poliklinisk utredning (4-6) istedenfor adekvat akuttbehandling.

Wyller \& Fure konstruerer en mulig motsetning mellom reperfusjonsbehandling og slagenhetsbehandling, men ser allikevel «ingen slik motsetning». Av vår artikkel fremgår det at heller ikke vi ser noen slik motsetning.

\section{Lars Thomassen}

Bergen

Lars Thomassen (f. 1947) er overlege ved Nevrologisk avdeling, Haukeland universitetssykehus.

Ingen oppgitte interessekonflikter.

Litteratur

1. Wyller TB, Furre B Ikke enten - eller, men både og i slagmedisinen. Tidsskr Nor Legeforen 2011. 131: 1277.

2. Næss H, Waje-Andreassen U, Brøgger J et al. Pasienter med akutt hjerneinfarkt innlagt i en slagenhet. Tidsskr Nor Legeforen 2011; 131: $814-8$

3. Thomassen L, Waje-Andreassen U, Næss $\mathrm{H}$ et al. Behandling av cerebrovaskulære sykdommer i en slagenhet. Tidsskr Nor Legeforen 2011; 131: 819-23.

4. Dahl T, Ellekjær H. Carotisstenose - utredning og behandling. Tidsskr Nor Legeforen 2009; 129: 2374-7.

5. Ellekjær H, Dahl T. Risikoskår og TIA-pasienter. Tidsskr Nor Legeforen 2010; 130: 14.

6. Helsedirektoratet. Nasjonal retningslinje for behandling og rehabilitering ved hjerneslag. www. helsedir.no/publikasjoner (1.7.2010).

Tilsvarsrett

Tidsskriftet praktiserer tilsvarsrett

i henhold til Vancouver-gruppens regler (www.icmje.org/publishing 5 correspond.html).

Dette innebærer at forfattere av vitenskapelige artikler som blir kommentert i spalten Brev til redaktøren, får anledning til å komme med tilsvar i samme nummer av Tidsskriftet. Ytterligere innlegg vil bli henvist til et senere nummer. 